ХГН. В обох групах середнє значення NGAL сечі не має статистично достовірних відмінностей $(\mathrm{p}<0,001)$. Показник NGAL сечі підвищений практично у однакової кількості хворих $-69 \%$ у хворих ХГН, 63\% - ГХ. Також, статистично достовірно ( $<0,001)$ визначено, що рівень IL-18 сироватки крові у хворих з ГХ нижче, ніж у хворих з ХГН. IL-18 сироватки крові в групі хворих ХГН підвищений у $69 \%$ пацієнтів, а в групі хворих ГХ - у $67 \%$ хворих.

Таким чином, виявлені нами кореляційні зв'язки між маркерами та даними морфологічного дослідження нирок у хворих ХХН: ГН дозволяють використовувати NGAL сироватки крові та сечі, IL-18 сироватки крові для оцінки ураження ТIT нирок у пацієнтів з ГН і ГХ. Незважаючи на збережену функцію нирок і відсутність МАУ (в 64\% випадків), показники, які оцінюють ТІТ нирок, у хворих ГХ є підвищеними.

Виявлення маркерів раннього ураження TIT нирок дозволить запобігти прогресуванню фіброзу TIT і підвищити ефективність раннього застосування інгібіторів ангіотензинперетворюючого ферменту.

\section{ВИСНОВКИ:}

1. Для оцінки ураження ТIT нирок у хворих на ХХН: ГН і ГХ можливе використання таких маркерів, як NGAL сироватки крові, сечі і IL18 сироватки крові.

2. NGAL сироватки крові найбільш точно відображає IФ та зміни тубулярної базальної мембрани; NGAL сечі - дистрофію епітелію канальців.

3. IL-18 сироватки крові $є$ показником дистрофії та некрозу епітелію канальців, ІФ.
4. Незважаючи на збережену функцію нирок і відсутність МАУ (в 64\% випадків), показники, які оцінюють ТІТ нирок, у хворих ГХ є підвищеними.

\section{ЛІТЕРАТУРА:}

1. Арутюнов Г.П. Тубулоинтерстициальный аппарат почки и его поражение при артериальной гипертензии / Г.П. Арутюнов, Л.Г. Оганезова // Клиническая нефрология. - 2011. - №1. C. 52-57.

2. Арутюнов Г.П. Экспериментальные модели поражения тубулоинтерстициальной ткани почек при артериальной гипертензии / Г.П. Арутюнов, А.В. Соколова, Л.Г. Оганезова // Клиническая нефрология. - 2011. - №2. - С. 75-78.

3. Пролетов Я.Ю. Роль некоторых биомаркеров в оценке характера хронического повреждения почек у пациентов с первичными гломерулопатиями / Я.Ю. Пролетов, Е.С. Саганова, О.В. Галкина и др. // Нефрология. - 2013. - №1(17). - С. 60-69.

4. Савош В.В. Клеточные механизмы формирования тубулоинтерстициальных изменений при первичных гломерулопатиях / В.В. Савош, Т.А. Летковская, Е.Д. Черствый и др // Мед. журнал. Белорусский государственный медицинский университет. - 2007. - №4. - С. 98-100.

5. Blumczynski A. Hypertensive nephropathy in children - do we diagnose early enough?/A. Blumczynski, J. Soltysiak, K. Lipkowska, M. Silska et al. // Blood Press. - 2012. - №21(4). - P. 233-9 [Epub $2012 \mathrm{Mar}$ 19].

6. Fasset R.G. Biomarkers in chronic kidney disease / R.G. Fasset, S.K. Venuthurupalli, G.C. Gobe et al. // Kidney Int. - 2011. - №80(8). - P. 806-821.

Надійшла до редакції 11.08.2014 Прийнята до друку 28.08.2014

(c) Лавренчук О.В., Порошина Т.В., Багдасарова І.В., Гайсенюк Ф.З., Драннік Г. М., 2014 УДК 616.65-002.2-008.8-078.7

О.В. ЛАВРЕНЧУК, Т.В. ПОРОШИНА, І.В. БАГДАСАРОВА, Ф.З. ГАЙСЕНЮК, Г.М. ДРАННІК ОСОБЛИВОСТІ ПРОДУКЦІЇ СЕКРЕТОРНОГО ЛЕЙКОПРОТЕАЗНОГО ІНГІБІТОРА (SLPI) У ДІТЕЙ, ХВОРИХ НА ГОСТРИЙ АБО ХРОНІЧНИЙ ПІЕЛОНЕФРИТ

\author{
O. LAVRENCHUK, T. POROSHINA, I. BAGDASAROVA, F. GAISENUK, G. DRANNIK
}

\title{
PECULIARITIES OF PRODUCTION OF SECRETORY LEUCOCYTE PROTEINASE INHIBITOR IN CHILDREN WITH ACUTE OR CHRONIC PYELONEPHRITIS
}

\author{
ДУ “Інститут нефрології НАМН України”, м. Київ \\ SI «Institute of Nephrology NAMS of Ukraine»
}

Ключові слова: пієлонефрит, діти, імунітет, секреторний лейкопротеазний інгібітор

Key words: pyelonephritis, children, immunity, secretory leucocyte proteinase inhibitor

Резюме. Цель: установить особенности про-

Лавренчук Ольга Василівна

lvi_lov@meta.ua дукции SLPIв крови и моче, определить тх взаимосвязь с клинико-лабораторными данными и особенностями течения пиелонефрита. 
Материалы и методы: Концентрацию SLPI определяли иммуноферментным методом в периферической крови и моче детей с пиелонефритом; из них острый пиелонефрит (ПН) диагностировано у 19 детей, обострение хронического ПН-у 12 и ХрПН в состоянии ремиссии - у 26 больных.

Результаты. Статистически достоверного отличия концентрации SLPI у детей острым и хроническим ПН, и, соответственно, в стадии обострения и ремиссии хронического ПН не установлено $(p<0,05)$. Упациентов с ОПН $(r K=0,605)$ и обострением ХрПН $(r K=536)$ существует корреляционная связь между концентрацией SLPI и количеством лимфоцитов в периферической крови $(p<0,05)$. Показатели уровней нейтрофилов как основних продуцентів протеаз, СОЭ и СРБ корреляционно не связаны с концентрацией SLPI в периферической крови и моче (p>0,05).

Заключение. Полученные данные свидетельствуют о роли SLPI в патогенезе острого и обострении хронического инфекционного воспаления в почках при участии лифоцитов как основных эффекторов адаптивного иммунного ответа.

Summary. Aims. The goal of the work is to determine the role and significance of the level of the secretory leucocyte proteinase inhibitor (SLPI) in children's blood and urine with acute (A) and chronic (Ch) pyelonephritis $(P N)$.

Materials and methods. In 26 patients with ChPN in the stage of remission and in 12 patients with ChPN at the stage of exacerbation, and in 19 patients with APN were used to study the level of SLPI in children's blood and urine by the enzyme-linked immunosorbent assay and corresponding test-systems.

Results. It was found that statistically significant difference between the concentration of SLPI in children with APN and ChPN, and, accordingly, in the acute stage and remission of ChPN not found $(p<0.05)$. There is a correlation between the concentration of SLPI and the number of lymphocytes in the peripheral blood $(p<0,05)$ in patients with $A P N(r K=0,605)$ and with ChPN at the stage of exacerbation $(r K=536)$. Correlations between the level of SLPI, C-reactive protein and erythrocyte sedimentation rate and the numbers of neutrophils is not installed $(p>0,05)$.

Conclusions. The results indicated the participation of SLPI into the pathogenesis of APN and ChPN at the stage of exacerbation.

ВСТУП. Захворюваність на інфекційні запалення сечової системи у всьому світі є високою та має тенденцію до збільшення. Відсутність комплексних досліджень з питань етіологічного спектру, топічної діагностики, лікування та профілактики їх рецидивів визначає доцільність виконання науково-дослідних робіт з урахуванням новітніх даних сучасної імунології [3].

Відомо, що запалення є універсальною, генетично запрограмованою реакцією на ушкодження різної природи. За правилом, запалення розвивається локально, але в його реалізації приймають участь практично усі системи організму, насамперед, імунна та нейроендокринна. Вважається, що імунні механізми є провідними на стадії ініціації патологічного процесу. Встановлено, що в імунних реакціях при запаленні можуть брати участь клітини не тільки загальної (інтегральної) та асоційованої з слизовими імунної системи. Учасниками запалення виступають також ендотелій, епітелій, стромальні клітини, резидентні та мігруючи в місце запалення імунокомпетентні клітини, у тому числі макрофаги і T-лімфоцити [6]. Залучення в процес запалення багатьох типів клітин і систем визначає формування складних механізмів регуляції запальної і імунної реактивності як на локальному, так i системному рівнях.

Особлива роль в генезі запалення належить толл-подібним (Toll-like) рецепторам (TLR), унікальність яких полягає у розпізнаванні груп консервативних молекул мікроорганизмів та структур ендогенного походження (так званих лігандів). Встановлено, що хронічне подразнення TLR рецепторів лігандами (у тому числі й сапрофітної флори, наприклад, LPS у складі ендотоксину (ЕT) грам-негативних бактерій, пептидогліканом, флагеліном, вірусною РНК, білками теплового шоку збудника чи господаря, некротичним дебрісом, фібріногеном, фібронектином призводить до тривалої продукції прозапальних цитокінів та індукції системного та локального запалення [5]. Дуже важливо, що визволення LPS відбувається не тільки під час руйнування бактеріальної клітини, а й при травмах, опіках, збільшенні кишкової проникності, внаслідок лікування вже існуючої бактеріальної інфекці [15]. У нормі відповіді з TLR чітко врегульовані, що попереджує запалення. Активація ж TLR спричиняє негайну відповідь клітин, спрямовану на знешкодження чужорідних патогенів, а саме: індукцію TLR-NF-kB сигнального шляху запалення - продукцію прозапальних цитокінів, оксиду азоту, вивільнення активних форм кисню [5]. Так, моноцити/макрофаги відповідають на початкові стимули від LPS TLR-4 й TLR-2-залежною секрецією TNF-б, IL-6, IL-8, що призводить до запальної реакції [7]. Уроепітеліоцити, позитивні за TLR-4, не відповідають на LPS через відсутність CD-14 рецепторів, проте відповідають TLR-4-залежною секрецією IL-8 (атрактант для нейтрофілів) при взаємодії з Р-фімбріями E.coli [2]. Активація TLR на дендритних клітинах моноцитарного походження 
призводить до прискорення фагосомального визрівання через формування та злиття лізосом 3 фагосомами й наступним процесінгом і завантаженням антигенних пептидів в головний комплекс гістосумісності II класу та індукції специфічної (адаптивної) імунної відповіді [5].

В цьому зв'язку важливими є нові дані щодо патогенетично значущих біологічних єфектів секреторного лейкопротеазного інгібітора secretory leucoprotease inhibitors (SLPI), що постійно виробляється епітеліальними клітинами слизових, нейтрофілами і макрофагами для протидії специфічних протеаз- катепсину G, еластази і трипсину з нейтрофілів, серіну з моноцитів, химази и триптази з тучних клітин [13, 14].

Згідно з новими даними експериментальних досліджень SLPI, посилений синтез яких є індукованим інфекційними антигенами (АГ) процесом [2], виказують ще й антибактериальні і протизапальні властивості.

Механізм SLPI-опосередкованої антибактеріальної активності полягає в зв'язуванні інгібітора протеази в бактеріальній мРНК і ДНК та інгібіції еластаза-опосредкованої деградації опсонинів і рецепторів, які приймають участь в фагоцитозі та регуляції протеолітичного процесінгу антимікробних пептидів, наприклад, кателіцідінів [3, 6]. В цьому зв'язку важливими $є$ дані щодо продукції SLPI також і епітеліальними клітинами ниркових канальців, що екпресують TLR, завдяки чому вони виконують функцію клітин природного імунного захисту - нейтрофілів і моноцитів, які першими взаємодіють і реагують на інфекційні АГ [8]. За таких умов ймовірна участь епітелільних клітин нирок в каскадних та мережевих цитокін-опосередкованих реакціях та підтримці хронічного запалення за мінімальної кількості імунокомпетентних клітин in situ [7].

За даними Subramaniyam D. et al. [13] in vitro LPS-індуковаване збільшення SLPI дозозалежно впливає на хемотаксис нейтрофілів (прямий зв'язок) та їх апоптоз (зворотній зв'язок); при цьому SLPI вже не впливає на IL-8-реліз та/чи адгезію нейтрофілів к фібронектину. Важливо, що SLPI пригнічує індуковану LPS і ліпотейхоєвою кіслотою (LTA) NF-kB активацію і TLRзалежну експресію генів прозапальних цитокінів (TNF-б, MCP-1, IL-6) в епітеліальних кліти- нах [9]. SLPI також приймають участь у процесах вільно-радикального окислення як одного з універсальних механізмів ушкодження клітин при запаленні. Так, SLPI впливає на збільшення глутатіона, що опосередково впливає на показники оксидативного стресу [11]. Преінкубація клітин зі SLPI призводить в LPS-стимульованих моноцитах до інгібіції простагландин-Н-синтази-2 (PGHS-2), ключового ферменту в PGE2 цАМФзалежного шляху синтезу матричних металопротеіназ (ММП). Інгібіція PGHS-2 відбувається в діапазоні 0,1-10 мкг/мл SLPI і супроводжується зниженням PGE2 внаслідок пригнічення інтерстиціальної колагенази (ММР-1) і желатінази В (ММР-9) [11].

В зв'язку з наведеними даними щодо протизапальних і антибактериальних властивостей SLPI при інфекційному запаленні, метою роботи було встановити особливості продукції SLPI в крові і сечі та їх взаємозв'язок з клініколабораторними даними і особливостями перебігу ПН у дітей.

МАТЕРІАЛИ ТА МЕТОДИ. В дослідження було включено 55 дітей, хворих на пієлонефрит (ПН). Після клініко-лабораторного обстеження пацієнти були розподілені на групи, з них гострий ПН спостерігався у 19 дітей, загострення (3) хронічного ПН - у 12 та ХрПН в стані ремісіі (Р) - у 26 хворих.

Визначення вмісту SLPI у периферичній крові та сечі проведено імуноферментним методом на багатоканальному аналізаторі "Sunrise" (Австрія) у відповідності до інструкцій виробників. Використовували тест-системи "Нуcult biotechnology" Human SLPI (Нідерланди).

Статистичну обробку результатів проводили за допомогою одно- та багатофакторного дисперсійного аналізу (програми "Microsoft Excel" i "MedStat"). Вибір процедур аналізу і критеріїв перевірки статистичних гіпотез програми "MedStat" відповідає міжнародним стандартам GCP, ICH та задовольняє вимогам доказової медицини (ЕВM) [1].

РЕЗУЛЬТАТИ ДОСЛІДЖЕННЯ. ІНДивідуальний аналіз показників рівнів SLPI, співставлення їх 3 клініко-лабораторними даними та особливостями перебігу захворювання представлений У таблиці 1.

Таблиця 1

Показники SLPI в сечі та периферичній крові дітей, хворих на ПН, за даними описової статистики

\begin{tabular}{|c|c|c|c|c|c|c|c|c|c|}
\hline $\begin{array}{c}\text { Групи } \\
\text { хворих }\end{array}$ & & $\begin{array}{c}\text { медіана } \\
\text { (пг/мл) }\end{array}$ & $\begin{array}{c}25 \% \\
\text { квартиль }\end{array}$ & $\begin{array}{c}75 \% \\
\text { квартиль }\end{array}$ & Мін. & Макс. & $\begin{array}{c}\text { похибка } \\
\text { медіани }\end{array}$ & $\begin{array}{c}\text { ліва } \\
\text { границя } \\
(95 \%)\end{array}$ & $\begin{array}{c}\text { права } \\
\text { границя } \\
(95 \%)\end{array}$ \\
\hline \multirow[t]{2}{*}{ ГПН } & кров & 3454,7 & 2911 & 3740,9 & 1099,5 & 4327,5 & 305,1 & 2314,8 & 3907,8 \\
\hline & сеча & 150,7 & 55,7 & 316 & 24,6 & 750,8 & 62,96 & 62,6 & 278 \\
\hline \multirow[t]{2}{*}{ ХрПН } & кров & 3263,9 & 2395,9 & 3483,3 & 1099,5 & 4327,5 & 243,6 & 2395,9 & 3483,3 \\
\hline & сеча & 81,8 & 40 & 194 & 0,7 & 750,8 & 32,09 & 57,1 & 150 \\
\hline
\end{tabular}


Продовження табл. 1

\begin{tabular}{|c|l|c|c|c|c|c|c|c|c|}
\hline $\begin{array}{c}\text { Групи } \\
\text { хворих }\end{array}$ & & $\begin{array}{c}\text { медіана } \\
\text { (пг/мл) }\end{array}$ & $\begin{array}{c}\text { 25\% } \\
\text { квартиль }\end{array}$ & $\begin{array}{c}\mathbf{7 5 \%} \\
\text { квартиль }\end{array}$ & Мін. & Макс. & похибка & $\begin{array}{c}\text { ліва } \\
\text { границия }\end{array}$ & $\begin{array}{c}\text { права } \\
\text { границя } \\
\text { (95\%) }\end{array}$ \\
\hline ХрПН, 3 & кров & 178,65 & 48,8 & 449,7 & 26,8 & 750,8 & 93,33 & 29,8 & 450,5 \\
\hline & сеча & 3235,3 & 2314,8 & 3554,9 & 1099,5 & 4327,5 & 409 & 2162,2 & 3740,9 \\
\hline ХрПН, Р & кров & 81 & 36,4 & 170,7 & 0,7 & 453,2 & 38,03 & 40 & 150 \\
\hline & сеча & 3397,5 & 2677,3 & 3421,3 & 2395,9 & 4012,7 & 213,5 & 2663 & 3483,3 \\
\hline
\end{tabular}

Порівняльний аналіз центральних тенденцій $(\mathrm{W}$-критерій Вілкоксона, W факт.=262,0) показників SLPI в сечі показав, що, незважаючи на майже двократне, за середніми даними, збільшення концентрації SLIP у хворих на ГПН, ніж при ХрПН, різниця не була статистично значущою $(\mathrm{p}=0,139)$. Більш очікуваними були результати порівняльного аналізу центральних тенденцій (W факт.=97,0) показників SLPI в крові у хворих на ГПН та ХПН, які достовірно не відрізнялись $(p=0,664)$. Не виявлено кореляційний взаємозв'язок $(\mathrm{p}>0,05)$ показників SLPI в сечі і крові у пацієнтів з ПН.

Не виявлено статистичної різниці рівнів SLPI в крові та сечі при порівнянні даних у хворих з гострим та клініко-лабораторними ознаками загострення хронічного ПН (p>0,05), та, відповідно, у хворих з загостренням ХрПН та в стані ремісії $(\mathrm{p}>0,05)$. Кореляційний зв’язок між показниками SLPI в крові та сечі у хворих з загостренням та ремісією ХрПН також відсутній $(\mathrm{p}>0,05)$

За індивідуальним аналізом показників рівнів SLIP та співставлення їх з особливостями перебігу захворювання, визначено, що у хворих на гострий ПН в активній стадії 8 дітей (7 з первинним ПН), спостерігався підвищений рівень протеаз в сечі різного ступеня вираженості. У 4 дітей дослідження сечі проводились в перші дні захворювання, до призначення антибактеріальної терапії, і показники SLIP становили від 146 до 360 пкг/мл, у решти хворих (4 дітей) в стані лабораторної ремісії, на тлі призначення антибактеріальної терапії. - від 47 до 100 пкг/мл,

Серед 12 пацієнтів з хронічним ПН в активній стадії, найвищій рівень SLIP в сечі (від 160 до 750 пкг/мл) визначався у $6(10,7 \%)$ дітей 3 вторинним варіантом ПН обумовленим СМР і рецидивуючим перебігом. У 2 дітей з хронічним вторинним ПН, ускладненим СМР, що знаходились в стані часткової лабораторної ремісії, показники протеаз були нижчі нормативних.

Хворі на первинний ПН $(4 / 7,1 \%)$ мали високий рівень SLIP в сечі при латентному перебігу захворювання з персистуючою лейкоцитурією в ан.сечі без клінічних та інших лабораторних ознак активності запального процесу.
Хронічний ПН в стані ремісії спостерігався у 26 хворих. Найвищі рівні SLIP в сечі - від 270 до 680 пкг/мл визначені у $9(16,0 \%)$ дітей з вторинним обструктивним ПН. Незначне зростання показників SLIP в сечі і рівнів в межах норми від 78 до 115 пкг/мл, документовано у 9 хворих з вторинним обструктивним ПН, після проведеної хірургічної корекції в анамнезі і відсутністю рецидивів на протязі 3 років. У 6 $(10,7 \%)$ дітей з хронічним первинним ПН рівні SLIP були в межах норми, або мали незначне підвищення до 79 пкг/мл у хворих з частими рецидивами ПН. Дитина з хронічною нирковою недостатністю 3 ступеня, що розвинулась на тлі безперервно рецидивуючого вторинного обструктивного ПН, мала найвищій показник SLIP сечi - 3774,2 пкг/мл.

Подальший аналіз даних SLPI та співставлення їх 3 основними лабораторними показниками активності запального процесу (ШОЕ, СРБ, нейтрофіли і лімфоцити) дозволив встановити закономірності продукції SLIP при ПН. Зв'язок між цими показниками оцінено методом кореляційного та регресійного аналізу. Кореляційні зв'язки оцінювали за допомогою критерія Кендала (кількісні показники представлені рангами); за визначенням, наявність кореляції не свідчить про наявність причинно-наслідкового зв'язку між двома ознаками. Причиннонаслідковий зв'язок варіабельності показників оцінювали за допомогою лінійного регресійного аналізу, показники SLPI включені в модель як залежна перемінна, а ШОЕ, СРБ, нейтрофіли і лімфоцити - незалежна (визначаюча). Критері$€$ статистичної достовірності даних був рівень $\mathrm{p}<0,05[1]$.

Проведений аналіз даних показав існування лінійного кореляційного зв'язку $(\mathrm{p}<0,05)$ між показниками SLPI та лімфоцитів в периферичній крові у хворих на ГПН $(\mathrm{rK}=0,605)$ та загострення $(\mathrm{rK}=536) \mathrm{XpПН.}$

На рис.1 наведено графічне зображення отриманих результатів.

Для аналізу адекватності моделі був проведений аналіз залишків - різниці фактичного значення ознаки і його теоретичного значення в межах побудованої моделі. Графічне зображення результатів аналізу наведено на рис. 2 . 


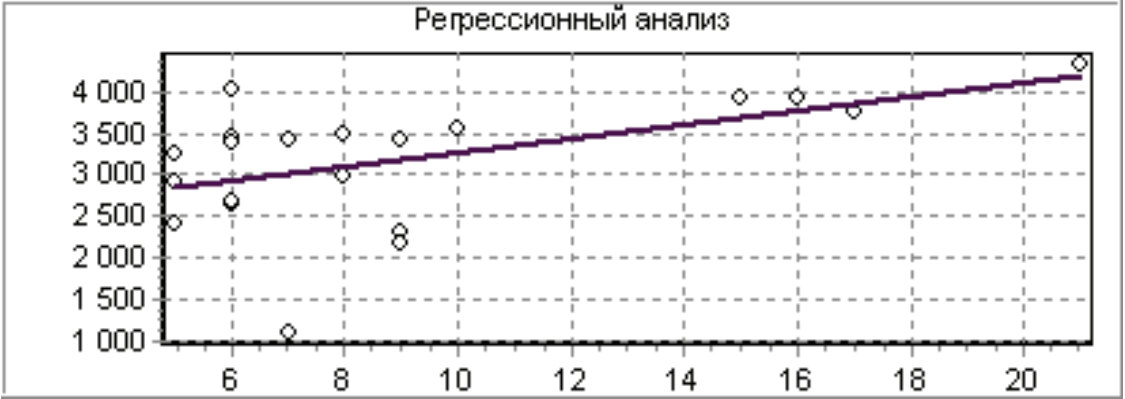

Рис. 1. Графічне зображення результатів кореляційного аналізу показників SLPI та лімфоцитів в периферичній крові $(\mathrm{p}=0,018)$.

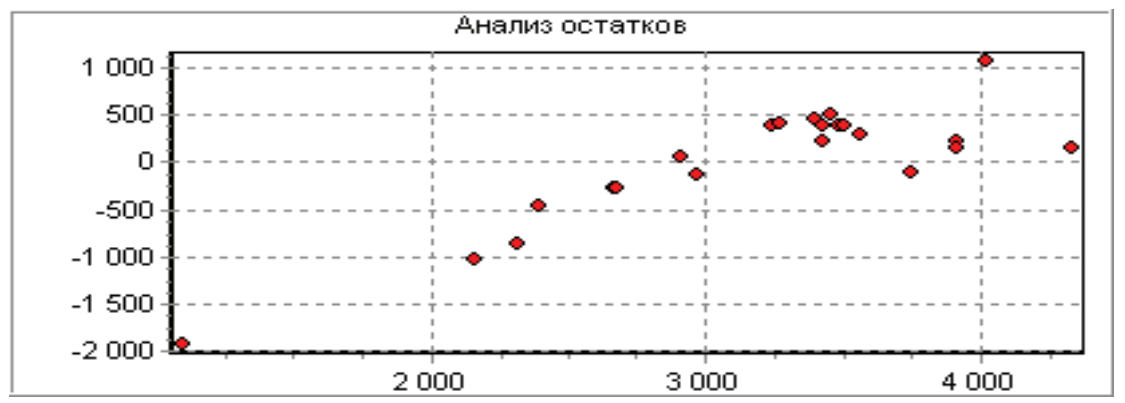

Рис. 2. Графічне зображення результатів аналізу різниці фактичного значення показників SLPI та лімфоцитів в периферичній крові і його теоретичного значення.

Встановлено, шо існує лінійний кореляційний зв'язок між залишками та результуючою ознакою. Це означає, що побудована лінійна модель не повністю описує залежність між цими двома ознаками, і на кожний з цих показників впливають додаткові фактори, які не увійшли в аналіз. Подальший аналіз даних показав, що показники ШОЕ, СРБ і нейтрофілів за даними кореляційного регресійного аналізу не впливають на коливання концентрації SLPI в периферичній крові у хворих на ГПН та загострення ХрПН (p>0,05).

Також не знайдено статично доведеної залежності між показниками SLPI (кров, сеча) та, відповідно, лімфоцитами, нейтрофілами, ШОЕ і СРБ у хворих на ПН в стадії ремісії ( $>>0,05)$.

Враховуючи дані літератури щодо посиленого синтезу SLPI під впливом інфекційних АГ, найбільш цікавим результатом проведеної роботи є дані про відсутність взаємозв'язку між показниками SLPI та нейтрофілів і його існування між SLPI та лімфоцитами в периферічній крові у хворих на гострий та з загостренням ХрПН. Як відомо, ГПН - це перший епізод бактеріальнообумовленого ураження інтерстицію нирки. При цьому саме інтерстицій нирки є місцем прояву реакцій адаптивного імунітету за участю, насамперед, лімфоцитів [4]. 3 урахуванням результатів Subramaniyam D. et al. [13], які показали, що під впливом LPS-залежної продукції SLPI відбувається збільшення хемотаксису нейтрофилів в 6 разів і зниження їх апоптотичної загибелі на 73\% $(\mathrm{p}=0,006)$, вважаємо, що саме ці ефекти SLPI на нейтрофіли пояснюють встановлені нами особливості реагування показників SLPI при ГПН.
Враховуючи, що на сьогоднішній день не встановлено поліморфізму та дефіциту гена SLPI [8], моніторинг концентрації SLPI в периферічнй крові у дітей є додатковим лабораторним показником активності ПН та залучення реакцій адаптивного (специфічного) імунітету в патогенез захворювання.

\section{ВИСНОВКИ:}

1. Встановлено, що в периферічний крові дітей, хворих на гострий і хронічний ПН, знаходиться значна концентрація SLPI, біологічні ефекти якого на системному на локальному рівнях задіяні у патогенезі інфекційного запалення в нирках.

2. Кількість в периферічній крові нейтрофілів як основних продуцентів протеаз кореляційно не зв'язана з концентрацією їх інгібітора SLPI. За даними кореляційного регресійного аналізу, відсутній взаємозв»язок $(\mathrm{r}=0, \mathrm{p}>0,05)$ показників SLPI, ШОЕ і СРБ у хворих на гострий та хронічний ПН .

3. В периферичній крові хворих на гострий і загострення хронічного ПН збільшення концентрації SLPI асоційовано зі збільшенням відносної кількості лімфоцитів. Існує міцний кореляційний зв'язок $(\mathrm{p}<0,05)$ між цими показниками у хворих на ГПН $(\mathrm{rK}=0,605)$ та, відповідно, з загостренням ХрПН $(\mathrm{rK}=536)$.

4. Отримані результати є доказом залучення SLPI у патогенез гострого та загострення хронічного інфекційного запалення в нирках за участю лімфоцитів як основних клітин адаптивної імунної відповіді. 


\section{ЛІТЕРАТУРА:}

1. Лях Ю. М. Основы компьютерной биостатистики : анализ информации в биологии, медицине и фармации статистическим пакетом MedStat / Ю. М. Лях, В. Г. Гурьянов, В. Н. Хоменко, О. А. Панченко / Донецк : 2006, 211 с.

2. Маянский $A$ H. Цитокины и медиаторные функции уроэпителия в воспалительных реакциях мочевыводящей системы / А. Н. Маянский // Цитокины и воспаление. - 2003. - № 3. C. $15-18$.

3. Основи нефрології / за редакцією М. О. Колесника // К.: Тов “Доктор-Медіа”, 2010. - 380 с.

4. Тареев Е. М. Клиническая нефрология. - М.: Медицина, 1983. - 880 с.

5. Хаитов Р. М. Значение функциональной активности толл-подобных рецепторов и других рецепторов врожденной иммуной системы в физиологии почек // Р. М. Хаитов, Б. В. Пинегин, М. В. Пащенков // Рос. Физиол. Журн. им. И. М.Сеченова - 2007. T. 91, №. 5. - С. 505-520.

6. Черешнев В.A. Иммунология воспаления: роль цитокиинов / В. А. Черешнев, Е. Ю. Гусев // Медицинская Иммунология. - 2001. - Т.3, № 3. - С. $361-368$.

7. Чикилева И. О. Двойственная роль толл-подобных рецепторов в регуляции противоопухолевого иммунитета / И. О. Чикилева, А. В. Караулов, Н. Ю. Анисимова, М. В. Киселевский // Иммунология. - 2010. - № 1. - С. 52-55.

8. Doumas $S$. Anti-Inflammatory and Antimicrobial Roles of Secretory Leukocyte Protease Inhibitor /
S. Doumas, A. Kolokotronis, P. Stefanopoulos // Infection and Immunity. - 2005. - №.3. - P. 12711274.

9. Greene C.M. Secretory leucoprotease inhibitor impairs toll-like receptor 2- and 4-mediated responses in monocytic cells / C. M. Greene, N. G. Mcelvaney, S. J. O, Neill [et al.] // Infection and immunity. - 2004 (June). - P. 3684-3689.

10. Ohlsson $S$. Novel distribution of the secretory leucocyte proteinase inhibitor in kidney / S. Ohlsson, I. Ljungkrantz, K. Ohlsson [et al.] // Mediators of Inflammation. - 2001. - Vol. 10. - P. 347-350.

11. Sallenave J. M. Secretory leukocyte protease inhibitor and elafin/trappin-2. Versatile mucosal antimicrobials and regulators of immunity / J. M. Sallenave // American journal of respiratory cell and molecular biology. - 2010. - Vol. 42, №.6. - P. 635-643.

12. Subramaniyam D. Secretory leukocyte protease inhibitor inhibits neutrophil apoptosis / D. Subramaniyam, C. Hollander, U. Westin [et al.] // Respirology. 2011. - Vol. 16. - №2. - P. 300-307.

13. Williams S. E. SLPI and elafin : one glove, many fingers / S. E. Williams, T. I. Brown, A. Roghanian, J. M. Sallenave // Clinical Science. - 2006. Vol. 110. - P. 21-35.

14. Xiaoyuan Wang. Endotoxins : structure, function and recognition / Xiaoyuan Wang, P. J. Quinn // Springer science+business media b.v., 2010. - 415 p.

Надійшла до редакції 05.08.2014 Прийнята до друку 27.08.2014

(C) Руденко А.В., Корніліна О.М., Мітченко М.В., Пасєчніков С.П., 2014

УДК: 616.61-002.3-06:616.62-002-097

А. РУДЕНКО, О. КОРНІЛІНА, М. МІТЧЕНКО, С. ПАСЕЧНІКОВ

СТАН ІМУНІТЕТУ СЕЧОВИВІДНИХ ШЛЯХІВ У ХВОРИХ НА ГОСТРИЙ ПІЕЛОНЕФРИТ ТА ЦИСТИТ

\section{A. RUDENKO, O. KORNILINA, N. MITCHENKO, S. PASECHNIKOV \\ STATE OF URINARY TRACTS' IMMUNITY IN PATIENTS WITH ACUTE PYELONEPHRITIS AND CYSTITIS}

$$
\begin{gathered}
\text { ДУ “Інститут урології НАМН України”, Київ } \\
\text { SI “Insitute of Urology NAMS of Ukraine”, Kyiv }
\end{gathered}
$$

Ключові слова: імунологічні показники сечі, гострий пієлонефрит, цистит

Key words: immunological indices of urine, acute pyelonephritis, cystitis

Резюме. Материал и методы. Было обследовано 64 женщины, больных острым пиелонефритом

(ОП), и 15 здоровых женщин, в моче которых определяли показатели, характеризующие состояние иммунитета мочевыводящих путей. Проведен анализ иммунологических данных мочи у больных с ОП (впервые выявленным) и при обострении хрониче-

Руденко Адель Вікторівна miclab@mail.ru ского пиелонефрита; с сопутствующим ииститом (острым или хроническим) или без него.

Результаты. В моче больных ОП отмечалось значительное увеличение уровня следуюших имму- 